\title{
Five eye-openers in my life of critical gerontology
}

\author{
By STEPHEN KATZ*
}

\begin{abstract}
This paper is a personal account of five "eye-opening" career experiences in the author's life that illustrate how biographical events shape opportunities and inspire knowledge-making in critical gerontology. Borrowing from Pierre Bourdieu's methodological concept of "fieldwork in philosophy," this account suggests that critical thinking only becomes meaningful in the lived contexts in which it is grounded, negotiated, transformed, and shared. Thus theoretical ideas about ageing, despite their abstract nature, have historical and unpredictable stories of their own that are worthy of a "fieldwork" approach. The paper also emphasises that the "critical" in critical gerontology includes a strong reflexive and self-critical dimension about the subjective conditions of doing gerontological research, especially in the face of gerontology's claim to be an objective science.
\end{abstract}

Keywords: critical gerontology, biography, reflection, history of ideas.

For this special issue of the International Journal of Ageing and Later Life celebrating its 10th anniversary, an invitation was sent out to write about our "personal reflections on the role of theory as eye-opener in gerontology."

* Stephen Katz, Department of Sociology, Trent University, Peterborough, Canada 
International Journal of Ageing and Later Life

In response I wish to extend this invitation to focus more reflexively on the role of personal career events as eye-openers in thinking about critical gerontology. Writing reflexively is challenging because it is an exercise in defamiliarisation to step back from our ideas and see how they came about. But where I have done this before, I have learned a great deal about my own thinking (Katz 2008). And when I read with interest about the reflexive careers of others, I see how their personal stories illuminate aspects of scholarly fields beyond the purview of their published works. For example, Clifford Geertz's (1988) book, Works and Lives: The Anthropologist as Author, is a wonderful introduction to how classical anthropologists constituted their discipline both as fieldwork scientists and as literary authors. In Sociology, there is a rich background of stories that remind us of how ideas overflow texts and reveal their nomadic and political nature. For instance, without the risks taken by Antonio Gramsci's partner Giulia, and her sister Tatiania, we would have no Prison Notebooks (Lauretis 1987). When Max and Marianne Weber visited America in 1904, they met W. E. B. Dubois and William James who inspired them to think and write about new ideas regarding religious cults, race relations, women's rights, and the moral dilemmas of democratic society (Scaff 1998). Urban Sociology developed with Georg Simmel and Louis Wirth not only because of their sociological inventiveness but also because Simmel lived in Berlin, the largest metropolis in Europe in the early 20th century, when he wrote "The metropolis and mental life" in 1903 and Wirth lived in bustling, multicultural and agonistic Chicago when he wrote "Urbanism as a way of life" in 1938.

The lives and environments of idea creators are important resources for understanding their ideas. Pierre Bourdieu captures this sense of ideas as living moments when he characterised much of what he did as a theorist as "fieldwork in philosophy," a phrase he borrowed from philosopher John Austin (Bourdieu 1990). For Bourdieu, philosophical fieldwork provides a key methodological inquiry into how ideas change and become embedded as socially meaningful. Thus, Bourdieu believes that good theory closes the gap between lived and abstracted worlds, and as evidence, he points to cases where this has happened, such as the intercultural use of "classificatory schemes" that began with Durkheim and was carried forward in the anthropological work of Marcel Mauss, Mary Douglas and Claude Lévi-Strauss 
(1990: 24-26). Similarly, I have argued that a reflexive-oriented fieldwork approach can be useful when looking at gerontological theory (Katz 2003). Bernice Neugarten's (1988) account of her career or W. Andrew Achenbaum's (2013) recent biography of Robert N. Butler, which Achenbaum treats as a "life review" following Butler's own conceptual method, are but two examples of how our gerontological ideas flow from often unpredictable biographical circumstances.

In my own work I have also tried to see where ideas live and breathe in gerontology. In chronicling gerontological handbooks I examined the textual vocabularies, literary designs and rhetorics by which gerontology represents itself as an authority on ageing (Katz 2000a). In a related study I traced the currency of the master-concept "activity" in gerontology as a theoretical model, a cultural ideal, an empirical instrument, a healthcare regime, a political rationality and a discursive resource (Katz 2000b). In a similar vein, my colleague Barbara Marshall and I have explored the meaning and ubiquity of "function" and "functionality" in relation to ageing (Katz 2006; Katz \& Marshall 2004). More recently I have worked on the meaning of "lifestyle" in gerontology (Katz 2013) and the applications of new ideas about memory loss, cognitive impairment and neurocultural developments in the ageing field (Katz 2012; Katz \& Peters 2008). In this latter area Kevin Peters and I have published a special issue of the journal Dementia (Katz \& Peters 2015) entitled "Voices from the field: Expert reflections on mild cognitive impairment," a series of nine interviews with leading researchers who talk about the intermix of their lives and ideas in order to explain their views on why the concept of Mild Cognitive Impairment (MCI) is so uncertain.

These stories, lives, ideas and investigations include eye-openers, to return to the theme of this writing. Indeed, the founding of Geriatrics in the early 20th century by Ignatius L. Nascher began with a very personal eye-opener. As Lawrence Cohen describes that founding moment:

Nascher later would retell the birth of geriatrics as the narrative of an epiphany, generated by an encounter with an old woman patient he had as a medical student. Visiting a slum workhouse with mostly elderly inmates, young Nascher and his medical preceptor are accosted by a woman complaining of her pain. The preceptor ignores the woman, and finally Nascher gets up the courage to ask why they are not trying to help her. "It's just old age," his preceptor explains. It is at this point that Nascher recounts the realization that 
International Journal of Ageing and Later Life

founded (and continues to dominate) the field: it's not just old age. In the declaration of old age's normality, Nascher had the vision of geriatrics. (Cohen 1998: 62)

Eye-openers, such as Nascher's, are critical moments that fold biography into thought in ways that evoke surprise, coincidence and the unexpected. Ultimately they can lead to new field-making questions, such as the one that sparked Nascher to ask how medical science can identify the relationship between the normal and the pathological in ageing; something we are still asking. In this spirit I want to reflect upon five eye-opening moments that pushed me to think critically about gerontological theory and connected me to wider questions about knowledge-making in the ageing research.

\section{The Samburu of Kenya: Elderhood Matters}

The first eye-opener was in the summer of 1973. I was a 21-year-old undergraduate at York University in Toronto when I registered for a course that took place in Kenya. With little background in African studies, I excitedly joined a group of 35 students and two professors as we travelled to northern Kenya to settle in an old game lodge amongst the Samburu people. The Samburu, like the Masaai, are traditional pastoralists who command a brilliant knowledge of the ecological relationships of their livestock, water and weather patterns, pasture environments and associated kinship structures including a sophisticated age-grade system based on the achievements of elderhood. Jomo Kenyatta, the first president of Kenya, was called Mzee which is an honorific term for "old man." Paul Spencer, the chief Samburu ethnographer entitled his first book The Samburu: A Study of Gerontocracy in a Nomadic Tribe (1965). The Samburu concept of life-course is such a powerful organising principle that it was impossible for me not to see how their respect for ageing put our culture's contempt of it into relief. I was amazed to learn how elders could bless and curse. For example, in a culture where the job of young warriors to protect their cattle can sometimes involve killing predators and raiders, the guilt (ngoki) of killing must be cleansed by all warriors being blessed by their ritual elders. The elders also permit the go-ahead for the major life-transition ceremonies such as male circumcision and marriage for younger Samburu. For the Samburu, age is the 
Eye-openers in my life of critical gerontology

imaginative resource that turns their dry savannah pasture lands into an agricultural fairground of dance and spirit. It is not surprising that Paul Spencer's second book about the Samburu was called Society and the Dance: The Social Anthropology of Process and Performance (1985). These learning experiences in Kenya opened both my eyes and mind to new ways of grasping the meaning of age and the diversity of cross-cultural age systems, which would greatly influence my future ideas about gerontology.

\section{Critical Theory and Gerontology}

My second eye-opener was inspired by two moments. In the Fall of 1984, I was teaching a social science course at York University. One of the assignments was for students to select an essay topic from a list I provided and one of the topics was on "ageing and old age" which only one student picked. A few weeks later the student came to tell me that there were very few reference books in the massive York library on her topic and those that were on the shelves were mostly out of date. I visited the library myself and saw that the section on ageing was embarrassingly sparse, especially compared to adjacent shelves of sociological material on social inequality, difference and identity. My student had been right in identifying a critical gap in the sociological literature and I thought that if ageing was so poorly represented in a large university library, what did this indicate about the general representation of ageing in society? Further, I realised that the critical forces revitalising other fields of knowledge had somehow bypassed gerontology despite the imaginative thinking of some of its early founders. I returned to advise my student to change her essay and write instead about the state of gerontology itself. She also developed a qualitative component and interviewed older women about what they thought about gerontology and gender relations. My student submitted an excellent paper and went on to develop a career in the gerontological field.

Later in the summer in 1985, I entered the PhD program in Sociology at York University in Toronto while continuing as a part-time instructor there. My studies began with a bang in a seminar taught by visiting professor Ernesto Laclau, whose work was mapping out the controversial 
International Journal of Ageing and Later Life

political logics between Marxism and poststructuralism. Laclau taught us about Judith Butler, Derrida, Foucault, Gadamer, Gramsci and Lacan, and their importance to theorising non-class social movements such as feminism, populism and environmentalism. I learned that while new kinds of poststructuralist theory were radicalising sociological thinking, this was not being translated to ageing research. When I combined this realisation with the experience of my student, I became interested in where the new critical theoretical work could find common ground with the study of ageing and how could they matter to each other. This question then became the inspiration for my $\mathrm{PhD}$ thesis and later for my book about the theoretical development of the gerontological sciences entitled Disciplining Old Age: The Formation of Gerontological Knowledge (Katz 1996).

\section{Nobody Is Old: Canadian Snowbirds in Florida}

My third eye-opening moment arose during a fieldwork project in 1999, where I travelled to the west coast of Florida to study Canadian snowbird communities. Snowbirds are mostly retired individuals or couples who spend their winter months in the warmth of Florida, Arizona, Texas and other "warm-belt" states or "sun-city" enclaves. In Europe there are parallel patterns with northern Europeans living in Spain or other Mediterranean areas. My project was to explore how older mobile Canadians were creating new spatial arrangements as they inhabited mobile home "parks" and gated communities near Florida's coastal areas. I was also curious about American-Canadian relationships in such communities. I chose to do my research in Charlotte County because it is one of the fastest growing retirement regions in the world with an average of $40-50 \%$ of the population being 65 years or older. It is also a popular area for Canadians who live in estates identified by Canadian references, such as Maple Leaf Estates and Victoria Estates.

However, when I went to talk to people about their snowbird lives in Charlotte County, I faced a dilemma. Although the county's services, housing, medical centres, restaurants and banks have practically been reinvented to cater to its older populations, almost everybody I talked to said they were neither "old" nor did their chronological age reflect 
Eye-openers in my life of critical gerontology

who they really were. When I asked to meet older residents at some of the estates, I was pointed to somebody else. "Oh, you want the Murray's next door, they're old!" Then again, the Murray's would point me to somebody even older in their opinion, and on it went. Everybody was retired, but nobody was really old. When I asked people if they took advantage of "early bird specials" at restaurants and "discount days" at the malls, most claimed that these were for "old people," not for them. While the language of seniorhood and active ageing was acceptable, the language of "old" or "elderly" was not. If health problems developed, these were seen as due to accidents, poor diet or just bad luck, but not due to ageing. Once at a supermarket, I asked the (older) manager if he could ask some of the parttime older workers if they would meet with me after work. Only one fellow showed up, who told me he was the only older person there since the rest were just "retired guys" looking to make a little extra money.

I thought there has to be some way to self-identify for these people based on age beyond the vague category of "senior" or "retired," but what was it? Marketing firms have this problem as well as they try to define age-based demographic targets for their products. At the same time, our youthobsessed, anti-ageing culture devalues all that is associated with age, such as wisdom, memory, tradition and generation and leaves behind far too few identities that meaningfully represent the ageing experience. Yet advocates demand more age-friendly and age-relevant housing, fashion, technologies, transportation and financial products, all of which require some form of positive age-identification undiluted by the postmodern blurring of age categories. But for those who live through age-related poverty or disability, their suffering is unfairly characterised as the outcome of individual failure to participate in supposedly empowering lifestyles that accord with responsible consumerism and the erasure of being old. The popularity of ideas like "successful" and "productive" ageing in American gerontology also promotes this untenable situation. So how can we identify this unmentionable human state that really is old without being trapped in discourses restricted either to positive or negative imagery? This was an eye-opening question for me as my fieldwork lead to a critique of our culture's coercive asymmetry between the subjective "feeling" of age and the body's outward manifestations of it. After Florida, in addition to a paper on snowbirds, 
International Journal of Ageing and Later Life

I wrote a conference paper presentation entitled, "Doing fieldwork on ageing when nobody is old," which helped to articulate my encounter with ageing identities within my own culture.

\section{Sex, Age and Functionality}

My fourth eye-opener happened on a cold winter afternoon in 2001 at Trent University in one of our senior common rooms. I was catching up with my colleague Barbara Marshall about her new research on sexuality. The "Viagra revolution" was upon us and we were chatting about the consequences of this wonder drug for older men and, more widely, for the concept of sexual performance itself. We realised that our work had much in common since we were both concerned with the social and gendered construction of the ageing body and the development of consumer, pharmaceutical and lifestyle industries around later life. We also discussed how sexuality in this case was becoming modelled according to a medical concept of "functionality"; hence, the traditional problem of impotence was being transformed into one of "erectile dysfunction." The opportunity to embrace Barbara's ideas on age and sexuality provided me with a new understanding of the construction of the ageing body as an assemblage of molecular functions.

After that meeting Barbara and I started exchanging ideas and organising literature searches and writing plans. I had already acquired some great historical materials on the medicalisation of the ageing body from the Wellcome Library for the History of Medicine in London to add to my readings in gerontology about functional health. Barbara had a wealth of data to share on sexuality, medicine, gender and pharmaceutical treatments, plus her own innovative work on gender and critical theory. Central to this eye-opening experience was co-authoring publications. In our research and writing, Barbara and I were so synchronised that we quickly wrote a manuscript entitled, "Forever functional: Male sexual fitness and the ageing body," a wordplay on Robert Wilson's Feminine Forever (1966), the bestseller about the power of hormone replacement therapy to prevent the supposed calamities of menopause. After our paper was published in the journal Body \& Society (Marshall \& Katz 2002), we had enough ideas 
Eye-openers in my life of critical gerontology

and material to write four more papers which we published between 2002 and 2012. Ten years of our successful sharing of ideas and publishing papers together has lead us now to investigate new areas of research and join with others in funded projects that continue our interests in the ageing body and society. Our work has also become one of the main features of a new Centre for Ageing and Society at Trent University.

\section{What's Critical about Critical Gerontology?}

Throughout the 1990s and 2000s, my research and writing had increasingly become part of a network of thinkers grouped under the banner of "critical gerontology," an interdisciplinary sub-field consisting mostly of humanities and social science scholars who challenge the assumptions of mainstream gerontology and biomedical models of ageing. Historically, the idea of "critical" harkens back to the critical theory of mid-20th century Marxists of the Frankfurt School for whom reflexivity was a methodological component of their critiques of political ideologies, cultural formations and instrumental methodologies. However, the approaches developed in critical gerontology expand upon this earlier orientation by advancing new research in political economy, feminism, social constructivism, the Humanities, the sociology of the body, cultural studies, media and technology (Calasanti \& Slevin 2006; Cole et al. 2010; Gilleard \& Higgs 2013; Twigg \& Martin 2015). My own work has also been motivated by Michel Foucault's idea of "critical curiosity," a style of thought that evokes "a readiness to find what surrounds us as strange and odd; a readiness to throw off familiar ways of thought and to look at the same things in a different way" (Foucault 1997: 325). Such critical curiosity fuels the essays in my book, Cultural Ageing: Life Course, Lifestyle and Senior Worlds (Katz 2005). Further, I have been influenced by the arguments advanced by Achenbaum (1995) and others that critical, philosophical and interdisciplinary impulses have been at the source of gerontology from the beginning. However, modern gerontology's pursuit of scientific status and affiliation with medical specialties has meant the loss of this broader creative foundation and the sense of gerontology as an art as well as a science. As such, critical gerontology can be seen as both returning to 
International Journal of Ageing and Later Life

its historical and intellectual roots as well as mapping out new research trends and radical directions.

As a self-identified critical gerontologist, my eye-opener came about during a symposium at The Gerontological Society of America (GSA) in 2007. I had been invited to be part of a symposium on "Gerontology and critical theory: Recent applications and emerging issues." My paper presentation was about ageing and functionality and a well-known American gerontologist was lined up to be the discussant. However, before the symposium occurred I was told by several colleagues that the discussant was not pleased with this idea that gerontologists could be divided between critical and mainstream camps, although this was not the topic of my paper. And when the discussion came up, he made it very clear that the purposes and goals of critical gerontology were not only unclear but served little purpose. After all, he aggressively argued, gerontologists have always been critical thinkers because of their critique of ageism and support for age-advocacy movements. Further, researchers in the social sciences have imported sociological ideas about social inequality and political economy into gerontology for decades and still feel no need to self-identify as critical gerontologists.

Despite the discussion period becoming heated and at times unpleasant, it was an eye-opener for me. While I had written about the need to clarify the meaning of gerontological criticality in the past, here was a face-to-face confrontation about it. If we are to defend critical gerontology we must be careful in explaining it. Many people research women, but not all are feminists. Many people research labour, but not all are Marxist-oriented political economists. And many people study ageing, but not all are critical thinkers. So what distinguishes "us" as critical gerontologists? Where are we really pushing the boundaries of gerontological theory? And who are we calling "uncritical" and why? In subsequent and very helpful email exchanges with colleagues from that conference, I thought more about defining critical gerontology and I began to outline what I consider some of its basic parameters, which I accumulated into a paper entitled "What is age studies" (Katz 2014) for Age, Culture, Humanities: An Interdisciplinary Journal. As I wrote the paper I had the GSA discussant's response in mind. His exchange with our symposium presenters reminded me that criticality has to be convincingly demonstrated and not just assumed, and that 
Eye-openers in my life of critical gerontology

finding the critical threads in any field must include a reflexive process of self-scrutiny. ${ }^{1}$

\section{Conclusions}

I have been very fortunate that the Kenyan Samburu, my York University student, my PhD course with Ernesto Laclau, the Canadian snowbirds in Florida, my colleague Barbara Marshall and my GSA symposium discussant have given me the opportunities to stop and reflect on my work. They have allowed me to see how ideas have a life of their own as they wander across boundaries, limits, expectations and disciplinary conventions into shared thought spaces where eye-opening and idea-making are part of the same process. I could add other moments to these five eyeopeners as they continue to intercept my thinking and push my work in unexpected ways. Sometimes the eye-opener has been a book, such as reading Julia Twigg's (2000) Bathing: The Body and Community Care whose focus on the bath and bathing has inspired me to look similarly at the ways falls and falling for older individuals are micro-sociological moments that reveal our wider cultural ambivalence about ageing. Or sometimes it is just a statement whose reflexive message keeps echoing in my mind such as Jon Hendricks saying that, "if we cannot see ourselves in our explanations, perhaps we should pause before proffering these explanations to the profession" (Hendricks 2008: 113). But overall, whatever the sources of inspiration that drive us to think and write about ageing, when our work and careers are looked at reflexively, they provide exciting individual portals into how biography, imagination, ideas and circumstance are connected to our pursuit of critical perspectives.

\footnotetext{
${ }^{1}$ There is a wider discussion about the relationship between age studies and gerontology developed in organisations such as the North American Network in Aging Studies (NANAS) and highlighted in the radical writing of Margaret Morganroth Gullette (e.g. Gullette 2013). However, there is general agreement that age studies is characterised as embracing non-scientific and non-medical approaches to age and ageing across the life-course, stemming from those fields often excluded in mainstream gerontological organisations and journals, such as the Humanities, performance/media/cultural studies, History and Philosophy.
} 
International Journal of Ageing and Later Life

\section{Corresponding Author}

Stephen Katz, Department of Sociology, Center for Aging and Society, Trent University, 1600 West Bank Drive, Peterborough, Ontario K9J 7B8, Canada. Email: SKatz@Trentu.ca

\section{References}

Achenbaum, W. A. (1995). Crossing Frontiers: Gerontology Emerges as a Science. New York: Cambridge University Press.

Achenbaum, W. A. (2013). Robert N. Butler: Visionary of Healthy Aging. New York: Columbia University Press.

Bourdieu, P. (1990). Fieldwork in philosophy (Interview). In In Other Words: Towards a Reflexive Sociology (pp. 3-33). Stanford, CA: Stanford University Press.

Calasanti, T. M. \& Slevin, K. F. (2006). Age Matters: Realigning Feminist Thinking. New York: Routledge.

Cohen, L. (1998). No Aging in India. Berkeley, CA: University of California Press.

Cole, T. R., Ray, R. E. \& Kastenbaum, R. (2010). Guide to Humanistic Studies in Aging: What Does It Mean to Grow Old? Baltimore, MD: The Johns Hopkins University Press.

De Lauretis, T. (1987). Gramsci notwithstanding, or, the left hand of history. In T. De Lauretis (ed.), Technologies of Gender (pp. 84-94). Bloomington, IN: Indiana University Press.

Foucault, M. (1997). The masked philosopher. In P. Rabinow (ed.), Michel Foucault: Ethics, Subjectivity and Truth (pp. 321-328). New York: The New Press.

Geertz, C. (1988). Works and Lives: The Anthropologist as Author. Cambridge: Polity Press.

Gilleard, C. \& Higgs, P. (2013). Ageing, Corporeality and Embodiment. London: Anthem Press.

Gullette, M. M. (2013). Agewise: Fighting the New Ageism in America. Chicago, IL: University of Chicago Press.

Hendricks, J. (2008). Coming of age. Journal of Aging Studies 22(2): 109-114. 
Katz, S. (1996). Disciplining Old Age: The Formation of Gerontological Knowledge. Charlottesville, VA: University Press of Virginia.

Katz, S. (2000a). Reflections on the gerontological handbook. In T. R. Cole \& R. E. Ray (eds.), Handbook of the Humanities and Aging (2nd ed., pp. 405-418). New York: Springer.

Katz, S. (2000b). Busy bodies: Activity, aging, and the management of everyday life. Journal of Aging Studies 14(2): 135-152.

Katz, S. (2003). Critical gerontological theory: Intellectual fieldwork and the nomadic life of ideas. In S. Biggs, J. Hendricks \& A. Lowenstein (eds.), The Need for Theory: Critical Approaches to Social Gerontology for the 21st Century (pp. 1-31). Amityville, NY: Baywood.

Katz, S. (2005). Cultural Aging: Life Course, Lifestyle and Senior Worlds. Peterborough, Ontario: Broadview Press.

Katz, S. (2006). From chronology to functionality: Critical reflections on the gerontology of the body. In J. Baars, D. Dannefer \& C. Phillipson (eds.), Aging, Globalization and Inequality (pp. 123-137). Amityville, NY: Baywood.

Katz, S. (2008). Thinking of age: Personal reflections on critical gerontology. Journal of Aging Studies 22(2): 140-146.

Katz, S. (2012). Embodied memory: Aging, neuroculture and the genealogy of mind. Occasion: Interdisciplinary Studies in the Humanities 4: 1-11.

Katz, S. (2013). Active and successful aging: Lifestyle as a gerontological idea. Recherches sociologiques et anthropologiques 44(1): 33-49.

Katz, S. (2014). What is age studies? Age, Culture, Humanities: An Interdisciplinary Journal 1(1): 5 .

Katz, S. \& Marshall, B. L. (2004). Is the 'functional' normal? Aging, sexuality and the bio-marking of successful living. History of the Human Sciences 17(1): 53-75.

Katz, S. \& Peters, K. R. (2008). Enhancing the mind? Memory medicine, dementia, and the aging brain. Journal of Aging Studies 22(4): 348-355.

Katz, S. \& Peters, K. R. (eds.) (2015). Special issue: Voices from the field: Expert reflections on Mild Cognitive Impairment. Dementia: The International Journal of Social Research and Practice 14(3): 285-382.

Marshall, B. L. \& Katz, S. (2002). Forever functional: Male sexual fitness and the aging body. Body $\mathcal{E}$ Society 8(4): 43-70.

Neugarten, B. L. (1988). The aging society and my academic life. In M. W. Riley (ed.), Sociological Lives (pp. 91-106). Newbury Park, CA: Sage. 
International Journal of Ageing and Later Life

Scaff, L. (1998). The "cool objectivity of sociation": Max Weber and Marianne Weber in America. History of the Human Sciences 11(2): 61-82. Twigg, J. (2000). Bathing: The Body and Community Care. London: Routledge. Twigg, J. \& Martin, W. (eds.) (2015). Routledge Handbook of Cultural Gerontology. London: Routledge. 